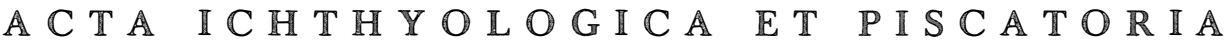 \\ Vol. X Fasc. 1 \\ Szczecin 1980
}

Bazyli CZECZUGA

Biochem istry

\section{CAROTENOIDS IN FISH. XXVIII. PLEURONECTIDAE FROM \\ THE BALTIC SEA}

\section{KAROTENOIDY U RYB. XXVII. PLEURONECTIDAE $\mathbb{Z}$ MORZA BAETYCKIEGO}

\author{
Department of General Biology \\ Białystok Medical Academy, Białystok, Poland
}

\begin{abstract}
By means of column and thin-layer chromatography, the author studied carotenoid contents in various body parts of dab, plaice and flounder. The studies showed qualitative and quantitative differences to occur between the species with respect to their carotenoid contents.
\end{abstract}

\section{INTRODUCTION}

The Southern Baltic fishing grounds yield several species of pleuronectids: Platichthys flesus, Limanda limanda, Platessa platessa, and - to a lower degree - Scophthalmus maximus and S. rhombus, the latter appearing rather sporadically in the area. The most common species, Platichthys flesus, makes up about $70-80 \%$ of the total pleuronectid landings, while Platessa platessa contributes several per cent, the remaining species playing no significant role.

The most intensive flatfish fisheries in the Southern Baltic take place in autumn winter, the catches contributing two-thirds of the total annual landings.

As a consequence of our long-term studies on the content of carotenoids - the vitamine A provitamines - in various fish species, we have become interested in the 
presence of these bioactive compounds in certain representatives of pleuronectids, a significant item, as already mentioned, in the Southern Baltic fisheries.

\section{MATERIAL AND METHODS}

The tests were carried out on the following three pleuronectid species occurring in the Baltic Sea: dab, Limanda limanda L., plaice, Platessa platessa L., and flounder, Platichthys flesus L. caught in summer 1977 from within the Polish territorial waters. The tests were performed on juveniles of the three species as well as on various body parts of adult dab and flounder.

The material to be examined was homogenised, soaked in bottles of dark glass in 95\% acetone in nitrogen atmosphere, and stored in a refrigerator until the analyses. Carotenoid pigments were separated by means of column and thin-layer chromatography. Prior to separation, the material was hydrolysed for $24 \mathrm{hrs}$ in $10 \% \mathrm{KOH}$ in nitrogen atmosphere at room temperature.

The hydrolysed material was released into $\mathrm{Al}_{2} \mathrm{O}_{3}$-filled columns ranging within $15-25 \mathrm{~cm}$ in length. The fractions were eluted using different solvent systems. Then an eluent used was evaporated and the residue dissolved in an appropriate solvent (see Czeczuga and Czerpak, 1976) in order to draw an absorption curve, peaks of which served, i.a., to identify the carotenoids involved. The F. Hoffman (La Roche, Basle) standards were used for $\beta$ - and $\gamma$-carotene, canthaxanthin, lutein, and zeaxanthin; a Unicam spectrophotometer was used to determine the absorption maxima.

Independently of column chromatography, the acetone extracts obtained were separated to fractions using thin-layer chromatography. Glass $15 \times 40 \mathrm{~cm}$ plates were covered with silica gel (Merck) and the acetone extract was transferred with a micropipette onto the starting line, various solvent systems being used as well (Czeczuga and Czerpak, 1976). The $R_{f}$ values were determined according to the commonly accepted procedures.

The carotenoids were identified from the absorption maximum of each fraction, $\mathbb{R}_{\mathrm{f}}$, epoxy test, and from the epiphase/hypophase ratio obtained. Quantitative relationships between the carotenoids were followed with the aid of Davies' method (Czeczuga and Czerpak, 1976).

\section{RESULTS}

Table 1 summarises the occurrence of various carotenoids found in the tested individuals of the three pleuronectid species. All the three species showed the presence of $\beta$-carotene and astaxanthin (both free and ester forms). A relatively low number of carotenoids was found to occur in the Platessa platessa individuals examined, the remaining two species containing many more caroteoids. Table 2 presents carotenoid 
Table 1

Carotenoids content in representatives of the Pleuronectidae family

\begin{tabular}{|c|c|c|c|}
\hline Carotenoid & $\begin{array}{r}\text { Limanda } \\
\text { limanda }\end{array}$ & $\begin{array}{l}\text { Platessa } \\
\text { platessa }\end{array}$ & $\begin{array}{c}\text { Platichthys } \\
\text { flesus }\end{array}$ \\
\hline $\begin{array}{l}\beta \text {-carotene } \\
\gamma \text {-carotene } \\
\gamma \text {-carotene derivative } \\
\epsilon \text {-carotene } \\
\beta \text {-cryptoxanthin } \\
\beta \text {-carotene epoxide } \\
\text { canthaxanthin } \\
\alpha \text {-doradexanthin } \\
\text { lutein } \\
\text { zeaxanthin } \\
\text { neothxanthin } \\
\text { phoenicoxanthin } \\
\text { diatoxanthin } \\
\text { taraxanthin } \\
\text { tunaxanthin } \\
\text { astaxanthin } \\
\text { astaxanthin ester } \\
\text { asterin acid } \\
\text { 4-hydroxy-4-keto- } \beta \text {-carotene } \\
\text { unknown }\end{array}$ & $\begin{array}{l}+ \\
+ \\
+ \\
+ \\
+ \\
+ \\
+ \\
+ \\
+ \\
+ \\
+ \\
+ \\
+ \\
+ \\
+ \\
+ \\
+\end{array}$ & $\begin{array}{l}+ \\
+ \\
+\end{array}$ & $\begin{array}{l}+ \\
+ \\
+ \\
+ \\
+ \\
+ \\
+ \\
+ \\
+ \\
+\end{array}$ \\
\hline
\end{tabular}

contents in the juveniles of the three species. Whereas $\beta$-cryptoxanthin and $\beta$-carotene prevailed in Limanda limanda (27.4 and $23.9 \%$, respectively), the remaining twc species' carotencid spectra were dominated by astaxanthin (free and ester). The total carotenoid content ranged from 23.435 (Platichthys flesus) to 57.040 (Platessa platessa) $\mu \mathrm{g} / \mathrm{g}$ wet weight.

Results of the chromatographic analyses of various body parts of dab are given in Table 3. In the adults of the species, 11 carotenoids were identified, of which $\gamma$-carotene, $\epsilon$-carotene, phoenicoxanthin, and 4-hydroxy-4-keto- $\beta$-carotene, relatively rare in fishes, ought to be mentioned. Canthaxanthin and lutein were the carotenoids occuring in every body part analysed. Additionally, both the adults and juveniles showed minimum amounts of astaxanthin ester, the carotenoid in the adults being detected in skin only (14.7\%). The highest total carotenoid contents were found to occur in skin, liver, and fins. Additionally, a high content of carotenoids in muscles of the dab individuals tested should be emphasised.

The occurrence of carotenords in various body parts of flounder is summarised in Table 4. The material analysed was found to contain 9 carotenoids, the most common of them being $\beta$-carotene epoxide, canthaxanthin, lutein, and $\alpha$-doradexanthin. The total 
Percentile composition of carotenoids in youngs representatives of the Pleuronectidae family $(\mathrm{O}+)$

\begin{tabular}{|c|c|c|c|}
\hline Carotenoid & $\begin{array}{r}\text { Limanda } \\
\text { limanda }\end{array}$ & $\begin{array}{l}\text { Platessa } \\
\text { platessa }\end{array}$ & $\begin{array}{l}\text { Platichthys } \\
\quad \text { flesus }\end{array}$ \\
\hline $\begin{array}{l}\beta \text {-carotene } \\
\epsilon \text {-carotene } \\
\alpha \text {-doradexanthin } \\
\beta \text {-cryptoxanthin } \\
\text { zeaxanthin } \\
\text { neothxanthin } \\
\text { diatoxanthin } \\
\text { taraxanthin } \\
\text { tunaxanthin } \\
\text { astaxanthin } \\
\text { astaxanthin ester } \\
\text { asterin acid }\end{array}$ & $\begin{array}{r}23.9 \\
\\
4.0 \\
27.4 \\
10.5 \\
7.3 \\
6.6 \\
14.7 \\
\\
\text { trace } \\
5.6\end{array}$ & $\begin{array}{r}41.2 \\
44.6 \\
4.5\end{array}$ & $\begin{array}{l}3.3 \\
7.0 \\
7.7\end{array}$ \\
\hline $\begin{array}{l}\text { Total content of carotenoids } \\
\text { in } \mu \mathrm{g} / \mathrm{g} \text { wet weight }\end{array}$ & 32.070 & 57.040 & 23.435 \\
\hline
\end{tabular}

Table 3

Percentile composition of carotenoids in some parts of the body the Limanda limanda $(1+)$

\begin{tabular}{|l|r|r|r|r|r|}
\hline \multicolumn{1}{|c|}{ Caretenoid } & fins & skin & muscles & liver & intestine \\
\hline$\beta$-carotene & 3.2 & 12.6 & & & \\
$\gamma$-carotene & & 30.1 & & & \\
$\epsilon$-carotene & & 7.8 & & 14.1 & \\
$\beta$-cryptoxanthin & 20.3 & & 6.9 & 9.5 & \\
$\beta$-carotene epoxide & 9.8 & 10.7 & 49.2 & 15.2 & 42.2 \\
canthaxanthin & 5.4 & & & 7.0 & \\
$\alpha$-doradexanthin & 5.8 & & & & \\
phoenicoxanthin & 49.2 & 16.5 & 43.9 & 30.8 & 57.8 \\
lutein & 6.3 & 14.7 & & 11.2 & \\
astaxanthin ester & & 7.6 & & & \\
4-hydroxy-4-keto- $\beta$-carotene & & & & & \\
unknown & 9.910 & 22.208 & 6.402 & 11.004 & 1.560 \\
& & & & \\
\hline Total content of carotenoids & & & & \\
\hline
\end{tabular}


Percentile composition of carotenoids in some parts of the body of the Platichthys flesus $(1+)$

\begin{tabular}{|l|r|r|r|r|r|}
\hline \multicolumn{1}{|c|}{ Caretenoid } & fins & skin & muscles & liver & intenstine \\
\hline$\beta$-carotene & 47.9 & & & 13.5 & \\
$\gamma$-carotene & & & & & 8.3 \\
$\gamma$-carotene derivative & 15.2 & 11.3 & 12.6 & 29.4 & 38.5 \\
$\beta$-carotene epoxide & 10.0 & 44.4 & 14.4 & trace & 23.6 \\
canthaxanthin & 3.4 & 3.0 & 4.4 & 5.6 & \\
- -doradexanthin & & 16.4 & & 56.5 & trace \\
phoenicoxanthin & 23.5 & 10.0 & 60.2 & 56.5 & 10.5 \\
lutein & & 6.8 & & & 19.1 \\
4-hydroxy-4-keto- $\beta$-carotene & & & & & \\
\hline unknown & & & & & \\
\hline \multicolumn{1}{c|}{ in $\mu \mathrm{g} / \mathrm{g}$ wet weight } & 71.628 & 57.117 & 8.557 & 20.131 & 5.637 \\
\hline
\end{tabular}

carotenoid content was at its highest in fins, skin, and liver. Similarly to dab, a relatively high amount carotenoids was found in muscles, while intestines showed the lowest content.

\section{DISCUSSION}

Comparing the three Baltic pleuronectids with respect to their carotenoid spectra, they were found to have only $\gamma$-carotene, astaxanthin, and astaxanthin ester in common. The plaice individuals showed a much lower number of carotenoids than the remaining two species, which is presumably due to the fact only the juveniles of Platessa platessa were examined, while of the remaining two species both juveniles and adults were subject to analyses. As shown by our earlier-published results, the diversity of carotenoids in fishes increases with age. Such a phenomenon was observed in populations of Salmo trutta morpha fario (Czeczuga, 1979 a) and Cyprinus carpio (Czeczuga, 1979 c).

The flatfish juveniles studied contained relatively high amounts of carotenoids the total content of which ranged from 23.435 (Platichthys flesus) to 57.040 (Platessa platessa) $\mu \mathrm{g} / \mathrm{g}$ wet weight. Whereas the principal carotenoids in Limanda limanda were $\beta$-cryptoxanthin and $\beta$-carotene, the remaining two species showed free astaxanthin and astaxanthin ester to be the main carotenoids. On the other hand, all the examined body parts of adult Limanda limanda contained only canthaxanthin and lutein. The adult Platichthys flesus showed to contain, in addition to canthaxanthin and lutein, also $\beta$-carotene epoxide in all the body parts analysed, the remaining carotenoids being present 


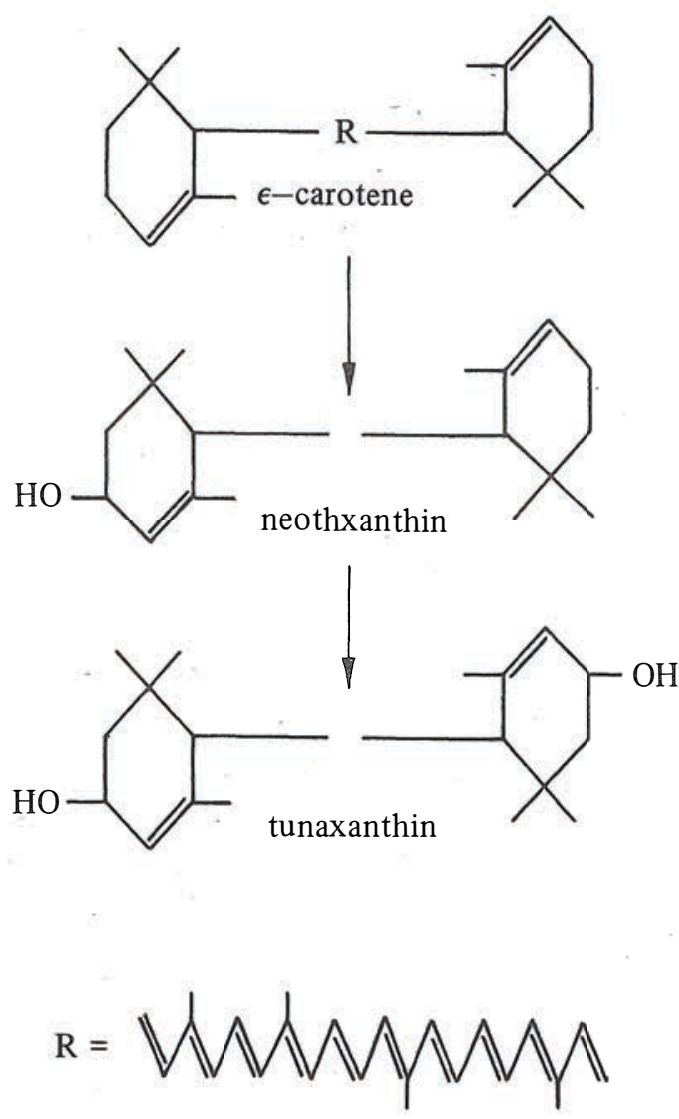

Fig. 1. Transformations of $\epsilon$-carotene in to neothxanthin and tunaxanthin

in some parts of the body only. It is worth noting that astaxanthin in its ester form was, in adults, found only in skin of Limanda limanda.

Noteworthy is the presence of $\epsilon$-carotene and its derivative, neothxanthin, in dab, and $\epsilon$-carotene and its derivative, tunaxanthin, in flounder. The carotenoids $\epsilon$-carotene and tunaxanthin have been several times identified in both marine and freshwater fishes. On the other hand, neothxanthin was determined for the first time in the marine species Neothunnus albacora (Tanaka et al., 1977), and subsequently detected in Cyprinus carpio (as $\epsilon$-carotene derivative) and Gasterosteus aculeatus by Czeczuga (1979 a, 1980). $\epsilon$-carotene is known to occur in algae (Czeczuga, $1979 \mathrm{~b}$ ) and it is presumably with food that this carotenoid is taken up by fishes and in turn transformed into its derivatives mentioned above (Fig. 1). Additionally, the examined individuals of Limanda limanda and Platichthys flesus showed the presence of $\alpha$-doradexanthin, the $\alpha$-carotene derivative, previously found in representatives of the Percichthyes (Matsuno and Katsuyama, 1976). 
Referring to the total carotenoid content in the examined body parts of adult Limanda limanda and Platichthys flesus, the highest amounts were found to occur in fins, skin, and liver, while the lowest in intestines. A particular attention should be paid to a relatively high carotenoid content in muscles of the species studied: 6.402 (Limanda limanda) and 8.557 (Platichthys flesus) $\mu \mathrm{g} / \mathrm{g}$ wet weight. These values should be regarded as high compared to those determined in muscles of some economically valuable freshwater and marine fish species. For example, the Salmo gairdneri muscle carotenoid content ranges within $0.018-0.400 \mu \mathrm{g} / \mathrm{g}$ wet weight, while the range of $0.037-0.320 \mu \mathrm{g} / \mathrm{g}$ wet weight was reported for $S$. trutta morpha fario; a similar range of $0.162-0.460 \mu \mathrm{g} / \mathrm{g}$ wet weight was observed in muscles of Coregonus albula (Czeczuga, 1975). As to marine species, muscles of cod, an important fishing target in the Baltic, contain 0.390-0.420 $\mu \mathrm{g}$ carotenoids/g wet weight, while in 9 Antarctic fish species as low a range as $0.057-0.122 \mu \mathrm{g} / \mathrm{g}$ wet weight was recorded (Czeczuga and Kłyszejko, 1978). As seen from these few comparisons, the examined representatives of the Baltic Pleuronectidae proved rich in carotenoids as the source of vitamine A.

\section{REFERENCES}

Czeczuga B., 1975: Carotenoids in fish. IV. Salmonidae and Thymallidae from polish waters.Hydrobiologia 46, 2-3: 223-239.

Czeczuga B., 1979 a: Carotenoids in fish. XX. Carotenoids in Salmo gairdneri Rich. and Salmo trutta morpha fario L. - Hydrobiologia 64, 3: 251-259.

Czeczuga B., 1979 b: Characteristic carotenoids in algae of different systematic position.- Nova Hedwigia XXXI, 1-2: 325-336.

Czeczuga B., 1979 c: Carotenoids in fish. XXII. Changes in carotenoids in Cyprinus carpio L. - Hydrobiologia 65 : in press.

Czeczuga B., 1980: Carotenoids in fish. XXVI. Pungitius pungitius (L.) and Gasterosteus aculeatus L. (Gasterosteidae).- Hydrobiologia 66: in press.

Czeczuga B., and Czerpak $\mathbb{R}$., 1976: Carotenoids in fish. VII. The kind of food and the content of carotenoids and vitamin A in Carassius carassius (L.) and Leucaspius delineatus (Heck.).- Acta Hydrobiol. 18, 1: 1-21.

Czeczuga B., and Kłyszejko B., 1978: Carotenoids in fish. XIV. The carotenoid content in the flesh of certain species from the Antarctic.- Hydrobiologia 60: 173-175.

Matsuno T., and Katsuyama M., 1976: Comparative biochemical studies of carotenoids in fishes - IX. On the nineteen species of fishes in the division Percichthyes. Bull. Jap. Soc. Sci. Fish. 42, 6: 645-649.

Tanaka Y., Shimamura F., and Katayama T., 1977: The existence of 3-hydroxy- $\epsilon$-carotene (neothxanthin) in kiwada, Neothunnus albacora.- Mem. Fac. Fish., Kagoshima Univ. 26: $33-37$.

Translated: mgr Teresa Radziejewska 


\section{KAROTENOIDY U RYB. XXVII \\ PLEURONECTIDAE Z MORZA BAETYCKIEGO}

\section{Streszczenie}

Autor stosując chromatografię kolumnową i cienkowarstwową badał występowanie poszczególnych karotenoidów w osobnikach młodocianych gładzicy, zimnicy i storni. Ponadto analizowano zawartość karotenoidów w poszczególnych częściach ciała wyrośniętych osobników zimnicy i storni.

W wyniku badań ustalono obecność takich karotenoidów jak: $\beta$-, $\gamma$ - $\epsilon$-carotene, $\gamma$-carotene derivative, $\beta$-cryptoxanthin, $\beta$-carotene epoxide, canthaxanthin, $\alpha$-doradexanthin, lutein, zeaxanthin, neothxanthin, phoenicoxanthin, diatoxanthin, taraxanthin, tunaxanthin, astaxanthin, astaxanthin ester, asterin acid oraz 4-hydroxy-4-keto- $\beta$-carotene. Podano również stosunki procentowe poszczególnych karotenoidów dla badanych gatunków Pleuronectidae. Okazało się, że mięśnie osobników badanych gatunków ryb w porównaniu do innych gatunków ryb morskich i słodkowodnych są bardzo zasobne w karotenoidy jako substancje biologicznie czynne.

\section{Чечуга Б.}

КАРОТИНОИДЫ У РЫБ XXVII

PLEURONECTIDAE ИЗ БАЛTИЙСКОГО МОРЯ

\section{Резюме}

Автор, применяя колончатую и тенкослойную х роматографию, исследовал присутствие ряда каротиноидов у молодых и выросших особей Limanda limanda, Platessa platessa, а также Platichthys flesus.

Установлено присутствие следующих каротиноидов: -, -, - каротин, производный -каротина, - криптоксантин, эпоксидная форма - каротина, кантаксантин, - дорадоксантин, дютеин, зеаксантин, неотксантин, фоэникоксантин, дятоксантин, тараксантин, тунаксантин, астаксантин, эстровая Форма астаксантина, квас астериновый, а также 4-гидрокси-4-кето- -каротин . Автор приводит также процентное содержание каротиноидов в различных органах исследуемых представителей Pleuronectidae. Оказалось, что мышшы исследуемых видов рыб по сравнению с другими морскими и пресноводными видами очень богаты такими биологически активными веществами, какими являются каротиноиды.

Adress:

Prof. Dr hab. Bazyli Czeczuga

Zakład Biologii Ogólnej

Akademii Medycznej

15-238 Białystok

Polska - Poland 